RESEARCH ARTICLE

Chemical composition and consumer acceptability of agidi (maize gel) enriched with orangefleshed sweet potato and soybean

F.L. Kolawole*, S.A. Oyeyinka, M.A. Balogun and F.F. Oluwabiyi

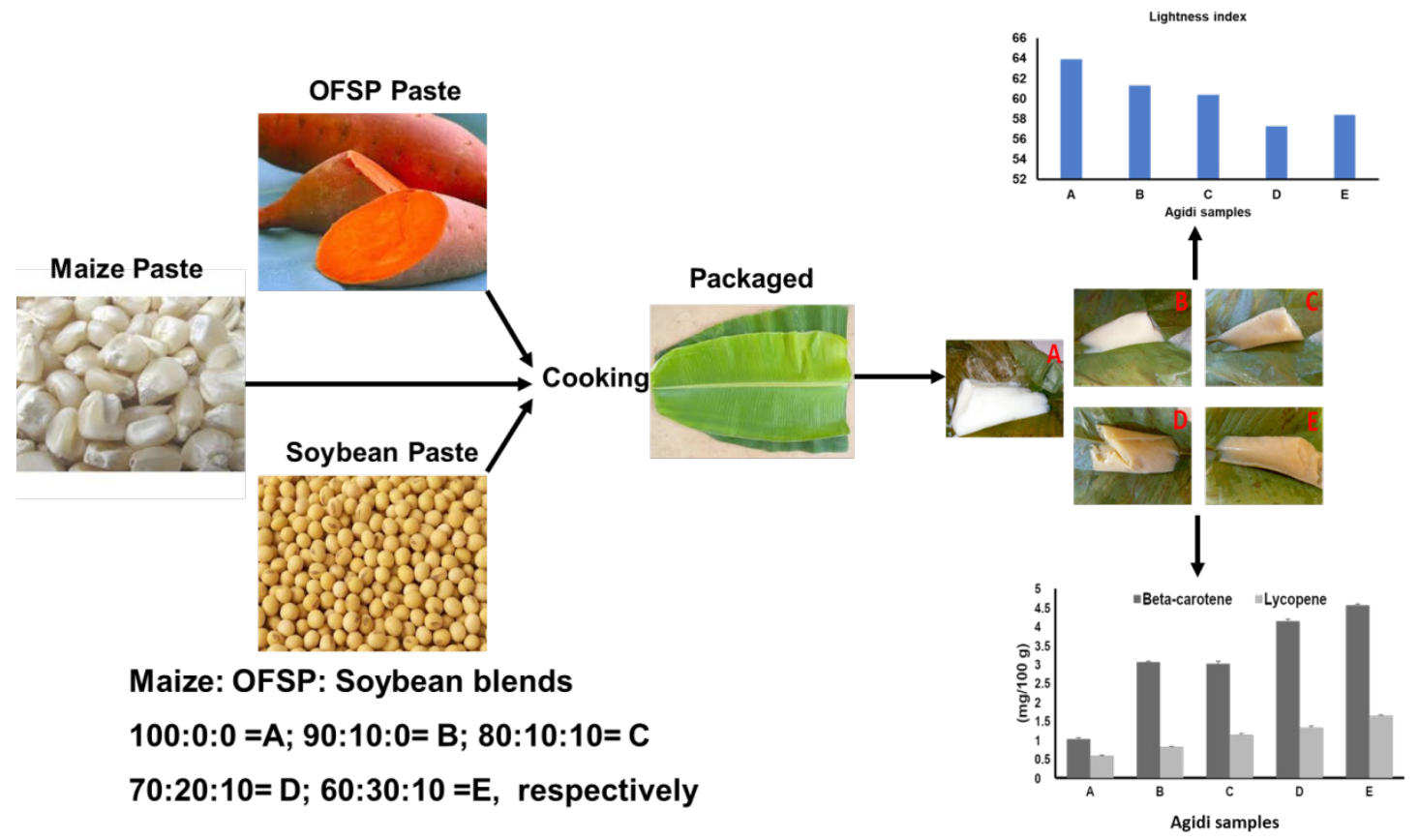

Graphical Abstract for the preparation of agidi from maize, orange fleshed sweet potato (OFSP) and soybean pastes

\title{
Highlights
}

- Protein-enriched agidi was prepared from maize, orange fleshed sweet potato \& soybean.

- Enriched agidi had improved mineral contents with calcium as the major mineral.

- Beta-carotene contents of enriched agidi increased by about 3 to 5 folds the initial level.

- Sensory properties were not significantly altered compared to the traditional agidi. 


\title{
RESEARCH ARTICLE
}

\section{Chemical composition and consumer acceptability of agidi (maize gel) enriched with orange- fleshed sweet potato and soybean}

\author{
F.L. Kolawole ${ }^{1, *}$, S.A. Oyeyinka ${ }^{2}$, M.A. Balogun ${ }^{1}$ and F.F. Oluwabiyi ${ }^{1}$ \\ ${ }^{1}$ Department of Home Economics and Food Science, University of Ilorin, Ilorin, Nigeria. \\ ${ }^{2}$ School of Agriculture and Food Technology, University of the South Pacific, Apoa, Samoa.
}

Received: 13/02/2020; Accepted: 31/10/2020

\begin{abstract}
Vitamin A deficiency remains a serious public-health concern in developing nations of the world. Staple foods such as maize gruel and maize gel may be used as carriers of beta-carotene that could be used to reduce the prevalence of this diseases, especially among children. In this study, maize gel (agidi) was enriched with orange fleshed sweet potato (OFSP) and soybean to improve the vitamin A and protein intake of regular consumers of agidi. The protein, ash, crude fibre and fat contents of the agidi samples increased with increased amounts of OFSP and soybean providing a balanced protein-energy diet. There was also a significant increase in the mineral, phytochemical and vitamin composition of the agidi-fortified samples when compared to the control (maize agidi). The significant increase in the betacarotene (pro-vitamin A) of the OFSP-soybean maize agidi is an advantage for consumers especially in the management of vitamin A deficiency (VAD). The enriched agidi samples compared well with maize agidi in some sensory characteristics and were also acceptable.
\end{abstract}

Keywords: Agidi, OFSP, Soybean, Enrichment, Maize.

\section{INTRODUCTION}

Agidi is a smooth-textured, semi-solid food, cooked from wet-milled and wet-sieved maize paste (Akobundu and Hoskins, 1982). It is a traditional fermented starchy food produced from maize, millet or sorghum (Ogiehor et al., 2005). Agidi is mostly consumed in many parts of West African countries including Nigeria (Ikya et al., 2013; Osungbaro, 1990a; Osungbaro, 1990b; Otunola et al., 2006). The consumption of agidi is becoming very popular, with acceptability cutting across the various multi-ethnic groups and socioeconomic classes (Ogiehor et al., 2005). Agidi is usually consumed by infants and adults (Akobundu and Hoskins, 1982) with stew, vegetables, bean cake or bean pudding (Abdulrahaman and Kolawole, 2006). Agidi has varying appearance in terms of colour, depending on the raw material used for its preparation. For example, agidi prepared from maize may have a cream to glassy white while those prepared from sorghum and millet produces light brown and grey colours, respectively.

Nutritionally, agidi is rich in carbohydrate (46.51$74.06 \%)$ and relatively low in protein (6.56-8.92\%) and fibre (0.74-1.92\%) (Balogun et al., 2016; Oguche et al., 2017). Due to its low fiber content, it is usually recommended during convalescence and weaning (Akobundu and Hoskins, 1982). In addition, most cereals including maize are low in protein, for example, maize is generally low in lysine, methionine, and tryptophan. Hence, cereal based products are usually enriched in order to improve their nutritive value. Previous studies reported significant improvement in the protein contents of maize gruel enriched with soybean (Balogun et al., 2016; Ikya et al., 2013). Enriching cereal-based foods with proteinrich leguminous crops and vitamins such as vitamin A are promising avenues for improving nutritional value of foods and combating many life-threatening diseases such as vitamin A deficiency, respectively. Vitamin A deficiency (VAD) remains a serious public-health and the leading cause of blindness in children from developing countries (Campagnoli and Smiddy, 2016). Agidi is majorly made from the white variety and this maize type is very low in beta carotene. However, the yellow variety of maize is rich in beta carotene $(0.25-2.5 \mu \mathrm{g} / \mathrm{g})$, a precursor of vitamin A, while the provitamin A varieties of maize contain up to about $15 \mu \mathrm{g} / \mathrm{g}$ (Nuss and Tanumihardjo, 2010). Plant materials such as orange fleshed sweet potato (OFSP) may be used in the development of value-added products which can be potentially used to address VAD. This seems plausible since they are good sources of beta-carotene (132-194 $\mu \mathrm{g} / \mathrm{g}$ ) (Van Jaarsveld et al., 2005). Thus, OFSP can be used to enhance the beta-carotene contents of staple foods such as agidi in developing nations of the world including Africa. Recently, Kolawole et al. (2020) suggested that OFSP paste and flour could be used by commercial food industries and even at household levels to enhance the nutritional intake of the vulnerable groups especially in addressing the problem of malnutrition and Vitamin A deficiency (VAD) affecting developing countries. Therefore, it seems plausible that OFSP can be incorporated into maize to enhance the nutrient content and antioxidant potentials of agidi. The utilization of OFSP in food applications is still limited. Hence its use in the enrichment of agidi may increase its consumption, thereby improving the dietary status of the consumers. In this study, the chemical composition and acceptability of agidi enriched with orange-fleshed sweet 
potato and soybean was investigated.

\section{MATERIALS AND METHODS}

White maize (Zea mays) and soybean (Glycine max) were purchased from Ipata Market, Ilorin East Local Government Area, Kwara State, Nigeria. Freshly harvested orangefleshed sweet potatoes (Ipomea batatas) were obtained from a farm in Agricultural and Rural Management Training Institute, Ilorin, Kwara State. The batch used in this study was harvested after a growing season of 30 weeks and were immediately transferred in jute bags to the Department of Home Economics and Food Science Laboratory, where they were immediately processed. The $\beta$-carotene and lycopene standards were purchased from Sigma-Aldrich Chemicals (St. Louis, MO, USA).

\section{Preparation of maize, OFSP and soybean paste}

Maize paste was produced using traditional methods with slight modifications. Briefly, cleaned maize grains (1 kg) were steeped in $4 \mathrm{~L}$ of potable water for $72 \mathrm{~h}$ at room temperature $\left(27 \pm 2{ }^{\circ} \mathrm{C}\right)$. The steep water was decanted and the grains were washed thoroughly with potable water. The grains were then milled with $4 \mathrm{~L}$ of water using attrition mill after which the slurry was then sieved with excess water using a muslin cloth. The filtrate was allowed to settle for $12 \mathrm{~h}$ and the supernatant decanted.

The OFSP tubers were processed into paste by washing $1 \mathrm{~kg}$ of OFSP in clean water. The cleaned tubers were peeled, diced and blanched in $1 \mathrm{~L}$ of boiling water for 15 min. The blanched OFSP roots were then milled together with the blanching water in a blender to obtain a puree.

Soybean paste was produced as described by Adesokan et al. (2011) with slight modifications. Briefly, Soybeans $(250 \mathrm{~g})$ was weighed and sorted. The beans were soaked in hot water $\left(60^{\circ} \mathrm{C}\right)$ for $2 \mathrm{~min}$, after which they were de-hulled to remove seed coats. The de-hulled beans were parboiled in $500 \mathrm{~mL}$ of hot water for $20 \mathrm{~min}$ and wet milled using a blender to obtain a paste.

\section{Preparation of agidi samples}

Agidi was produced following the method of Oguche et al. (2017) with slight modifications. Slurry made from $500 \mathrm{~g}$ of maize paste mixed with $300 \mathrm{~mL}$ of potable water, was added to $1000 \mathrm{~mL}$ of boiling water with continuous stirring (for about $10 \mathrm{~min}$ ) until custard-like semisolid gruels were formed. Each sample was wrapped in banana leaves and left to cool for $2 \mathrm{~h}$ at room temperature and subjected to chemical and sensory analyses. The above method was used to prepare maize: OFSP: soybean blends in different ratios as shown in Table 1.

\section{Proximate analysis}

Moisture, fat and ash contents were determined using AOAC (2000) methods. Protein content was determined by the Kjeldahl method $(6.25 \times \mathrm{N})$ and total carbohydrate was calculated by the difference. Fibre content was determined by standard laboratory procedure.

\section{Mineral Analysis}

Mineral content of the sample was determined as described previously (Oyeyinka et al., 2018a), using Inductively Coupled Plasma (ICP) spectroscopy. Samples were aciddigested by the addition of $1.0 \mathrm{~mL}$ of $55 \%(\mathrm{v} / \mathrm{v}) \mathrm{HNO}_{3}$.

\section{Determination of Beta-carotene and Lycopene}

Beta-carotene and lycopene contents of the samples were determined according to the method of Kumari et al. (2011) and described by Kolawole et al. (2017). Briefly, samples were extracted with methanol and the dried methanolic extract $(100 \mathrm{mg})$ was mixed with $10.0 \mathrm{~mL}$ of acetone-hexane mixture (4:6) for $1 \mathrm{~min}$ and filtered. The absorbance was recorded at three different wavelengths of 453, 505 and $663 \mathrm{~nm}$. Beta-carotene was calculated as: $0.216 \times \mathrm{A}_{663}-0.304 \times \mathrm{A}_{505}+0.452 \times \mathrm{A}_{453}$, while lycopene content was estimated as: $-0.0458 \times \mathrm{nA}_{663}+0.372 \times \mathrm{A}_{505}-$ $0.0806 \times \mathrm{A}_{453}$.

\section{Colour}

The CIE tristimulus L, a and $\mathrm{b}$ parameters of the agidi samples were measured using a chroma meter (ColourFlexDiffuse) as reported previously (Oyeyinka et al., 2018b). The colorimeter operates on the CIE L, a and b color schemes, L (lightness) axis - 0 is black, 100 is white, a (red-green) axis - positive values are red; negative values are green and 0 is neutral, $b$ (yellow-blue) axis - positive values are yellow; negative values are blue and 0 is neutral. The instrument was standardized and the samples were placed in the sample holder. Color measurement was determined in triplicates.

\section{Sensory evaluation}

The descriptive test was used for the sensory evaluation of the various agidi samples. A 50-member panel was put up made up of University of Ilorin students that are familiar to agidi. A preliminary study was organized and members of the panel gave different descriptions of attributes of agidi

Table 1: Formulation of maize, orange fleshed sweet potato and soybean in maize gel (w/w).

\begin{tabular}{cccc}
\hline Samples & Maize & OFSP & Soybean \\
\hline A & 100 & 0 & 0 \\
B & 90 & 10 & 0 \\
C & 80 & 10 & 10 \\
D & 70 & 20 & 10 \\
E & 60 & 30 & 10 \\
\hline
\end{tabular}


Table 2: Descriptive sensory chart.

\begin{tabular}{ll}
\hline \multicolumn{1}{c}{ Sensory attribute } & \multicolumn{1}{c}{ Definition } \\
\hline Colour & Slightly or dull orange colour \\
Pale orange & Milky cream colour \\
Cream & Plain white paper colour \\
White & Chemical-like, taste sensation of which coffee is typical \\
Taste & A taste sensation related to sugar \\
Bitter & A taste sensation that is acidic and sharp \\
& \\
Sweet (sugary) & A textural characteristics of a clean mouth feel \\
Sour & Presence of small grainy or sandy particles \\
Texture & Uneven mouth feel with tiny chunks \\
Smooth & A viscous consistency \\
Gritty & A consistency similar to that of water \\
Lumpy & Consistency \\
Watery & Thick
\end{tabular}

(Source: Akissoe et al., 2015)

based on colour, taste, texture, consistency and overall acceptability. The results obtained were analyzed and a descriptive test chart (Table 2) was developed for the study.

\section{Statistical analysis}

Duplicate samples were prepared and analyses was conducted in triplicate. Data was analyzed using one-way analysis of variance (ANOVA) and means were compared using the Fisher Least Significant Difference (LSD) test $(p \leq 0.05)$ using the Statistical Package for the Social Sciences (SPSS) Version 16.0 for Windows (SPSS Inc., Chicago, IL, USA).

\section{RESULTS AND DISCUSSION}

\section{Proximate composition of agidi samples}

With the exception of carbohydrate, ash, fat, fibre, protein and moisture contents increased with increase in either OFSP or soybean (Table 3). Agidi samples generally had high amounts of carbohydrate (53.28-55.9\%) and moisture (35.44-36.97\%), but the ash (1.21-1.39\%), fat (0.85-1.01\%) and protein contents (5.59-6.31\%) were very low (Table 3 ). High amount of carbohydrate is expected since the bulk of the raw material for making agidi is maize. This is one of the major reasons for enriching agidi and other cereal based staple with leguminous crops such as soybean and Bambara groundnut. For example, some authors reported significant increase in the protein contents of maize gruel or agidi enriched with soybean (Balogun et al., 2016; Ikya et al., 2013; Oguche et al., 2017) or Bambara groundnut (Zakari et al., 2010). Oguche et al. (2017), found that the protein content of agidi increased more than 100 folds when $20 \%$ of soybean was added to maize paste. In the current study, OFSP and soybean were used in varying ratios to achieve different objectives of enriching the agidi with beta carotene and protein respectively. Protein contents (approx. 6.02\%) recorded in this study for agidi enriched with $10 \%$ soybean were much lower than values previously reported for agidi enriched with 20 and 30\% soybean (Oguche et al., 2017). Differences in the protein contents obviously resulted from the varying proportions of soybean used. Furthermore, it appears that the OFSP contributed to the increase in protein content of the agidi samples. At the same soybean levels $(10 \%)$, the protein content of the samples slightly increased from 6.11 to $6.31 \%$ (Table 3 ). OFSP has been reported to contain small amounts of protein (5.74-9.72) (Adeola et al., 2019). These relatively small quantities of protein possibly contributed to the slight but significant increase in protein in the samples.

As stated previously, the moisture content of the samples was high (approx. 36\%) and compares favorably with the literature (Balogun et al., 2016; Oguche et al., 2017). High moisture content in agidi could be due to the processing method since these samples were cooked pastes. Moisture 
Table 3: Proximate compositions of agidi from maize, OFSP and soybean.

\begin{tabular}{cccccccc}
\hline Samples & Moisture & Ash & Fat & Protein & Fibre & ${ }^{*}$ CHO & Energy (Kcal/100g) \\
\hline A & $35.44^{\mathrm{c}}$ & $1.21^{\mathrm{c}}$ & $0.85^{\mathrm{d}}$ & $5.59^{\mathrm{e}}$ & $0.94^{\mathrm{b}}$ & $55.98^{\mathrm{a}}$ & $253.91^{\mathrm{a}}$ \\
B & $35.48^{\mathrm{c}}$ & $1.24^{\mathrm{c}}$ & $0.88^{\mathrm{c}}$ & $5.83^{\mathrm{d}}$ & $0.96^{\mathrm{b}}$ & $55.62^{\mathrm{b}}$ & $253.74^{\mathrm{a}}$ \\
C & $35.85^{\mathrm{b}}$ & $1.29^{\mathrm{b}}$ & $0.91^{\mathrm{c}}$ & $6.11^{\mathrm{c}}$ & $0.98^{\mathrm{b}}$ & $54.86^{\mathrm{c}}$ & $252.07^{\mathrm{b}}$ \\
D & $36.93^{\mathrm{a}}$ & $1.37^{\mathrm{a}}$ & $0.98^{\mathrm{b}}$ & $6.27^{\mathrm{b}}$ & $1.03^{\mathrm{a}}$ & $53.44^{\mathrm{d}}$ & $247.60^{\mathrm{c}}$ \\
E & $36.97^{\mathrm{a}}$ & $1.39^{\mathrm{a}}$ & $1.01^{\mathrm{a}}$ & $6.31^{\mathrm{a}}$ & $1.05^{\mathrm{a}}$ & $53.28^{\mathrm{e}}$ & $247.45^{\mathrm{c}}$ \\
\hline
\end{tabular}

Mean along the same column with different superscripts are significantly $(\mathrm{p}<0.05)$ different.

*CHO: Carbohydrate

Table 4: Mineral composition of agidi from maize, OFSP and soybean (mg/100 g).

\begin{tabular}{lccccc}
\hline Mineral & $\mathbf{A}$ & $\mathbf{B}$ & $\mathbf{C}$ & $\mathbf{D}$ & $\mathbf{E}$ \\
\hline Calcium & $236.10^{\mathrm{d}} \pm 0.42$ & $237.60^{\mathrm{d}} \pm 0.14$ & $240.90^{\mathrm{c}} \pm 0.42$ & $250.45^{\mathrm{b}} \pm 0.35$ & $294.00^{\mathrm{a}} \pm 0.57$ \\
Magnesium & $47.30^{\mathrm{a}} \pm 3.82$ & $46.40^{\mathrm{a}} \pm 1.27$ & $46.95^{\mathrm{a}} \pm 0.49$ & $46.55^{\mathrm{a}} \pm 0.35$ & $46.95^{\mathrm{a}} \pm 0.92$ \\
Potassium & $16.00^{\mathrm{c}} \pm 1.41$ & $23.50^{\mathrm{b}} \pm 3.54$ & $25.50^{\mathrm{b}} \pm 0.71$ & $27.50^{\mathrm{b}} \pm 2.12$ & $30.50^{\mathrm{a}} \pm 0.71$ \\
Phosphorus & $23.00^{\mathrm{c}} \pm 1.41$ & $25.50^{\mathrm{b}} \pm 0.71$ & $25.50^{\mathrm{b}} \pm 0.71$ & $26.50^{\mathrm{b}} \pm 0.71$ & $33.50^{\mathrm{a}} \pm 0.71$ \\
Iron & $3.15^{\mathrm{a}} \pm 1.26$ & $3.70^{\mathrm{a}} \pm 1.41$ & $3.80^{\mathrm{a}} \pm 7.07$ & $5.10^{\mathrm{a}} \pm 0.00$ & $5.20^{\mathrm{a}} \pm 7.07$ \\
Zinc & $2.40^{\mathrm{d}} \pm 1.41$ & $3.80^{\mathrm{c}} \pm 1.41$ & $4.55^{\mathrm{b}} \pm 2.12$ & $4.85^{\mathrm{ab}} \pm 0.71$ & $5.00^{\mathrm{a}} \pm 1.41$ \\
Sodium & $1.90^{\mathrm{a}} \pm 1.41$ & $1.35^{\mathrm{b}} \pm 2.12$ & $1.40^{\mathrm{b}} \pm 1.41$ & $2.20^{\mathrm{a}} \pm 0.00$ & $2.15^{\mathrm{a}} \pm 0.71$ \\
Copper & $2.70^{\mathrm{c}} \pm 1.41$ & $3.25^{\mathrm{b}} \pm 0.71$ & $3.30^{\mathrm{b}} \pm 0.00$ & $3.45^{\mathrm{b}} \pm 0.71$ & $4.55^{\mathrm{a}} \pm 0.71$ \\
\hline
\end{tabular}

Mean along the same column with different superscripts are significantly $(\mathrm{p}<0.05)$ different.

content is an important indicator of the shelf-life of foods (Oguche et al., 2017). Thus, the high moisture contents of the samples predispose them to rapid spoilage, and hence, there may be needed to consume as soon as possible or to refrigerate where this option is available.

\section{Mineral composition of agidi samples}

Calcium (236.10-294.00 mg/100 g) is the major mineral present in the agidi samples (Table 4). Following calcium in quantities are magnesium (46.40-47.30 mg/100 g), phosphorus (23.00-33.50 mg/100 g) and potassium (16.00$30.50 \mathrm{mg} / 100 \mathrm{~g})$. Other mineral elements i.e. iron (3.15$5.20 \mathrm{mg} / 100 \mathrm{~g})$, zinc $(2.40-5.00 \mathrm{mg} / 100 \mathrm{~g})$, sodium $(1.35$ $2.20 \mathrm{mg} / 100 \mathrm{~g})$ and copper $(2.70-4.55 \mathrm{mg} / 100 \mathrm{~g})$ were present in small quantities (Table 4). The addition of $10 \%$ OFSP alone to agidi significantly increased the levels of calcium $(\mathrm{Ca})$, potassium $(\mathrm{K})$, phosphorus $(\mathrm{P})$, iron $(\mathrm{Fe})$, Zinc $(\mathrm{Zn})$ and Copper $(\mathrm{Cu})$, but the contents of sodium $(\mathrm{Na})$ and Magnesium $(\mathrm{Mg})$ reduced (Table 4). However, with the addition of $10 \%$ soybean to the agidi containing $10 \%$ OFSP, there seems to be an increase in both $\mathrm{Na}$ and $\mathrm{Mg}$, suggesting that soybean is a good source of both minerals $(\mathrm{Na}$ and $\mathrm{Mg}$ ). Increasing the proportion of OFSP in the formulation further increased the mineral contents of the agidi samples. $\mathrm{Mg}$ is an essential nutrient in the appropriate utilization of vitamin $\mathrm{B}$ and $\mathrm{E}$ and functions with other minerals such as $\mathrm{Ca}, \mathrm{Na}$, and $\mathrm{K}$ in maintaining osmotic balance (Nafiu et al., 2011), while $\mathrm{K}$ has been reported to help in reducing blood pressure (Ranhotra et al., 1998).

\section{Beta-carotene and lycopene contents of agidi samples}

The $\beta$-carotene contents of the agidi samples varied between 1.02 and $4.56 \mathrm{mg} / 100 \mathrm{~g}$ (Figure 1). In general, the $\beta$-carotene content of the OFSP enriched sample was significantly higher than the sample without OFSP, reaching up to 3-5 times of the initial level. Yellow maize variety may contain up to $2.5 \mu \mathrm{g} / \mathrm{g} \beta$-carotene depending on cultivar, while the provitamin A type contains up to about $15 \mu \mathrm{g} / \mathrm{g}$ (Nuss and Tanumihardjo, 2010). Thus, the higher $\beta$-carotene content of the OFSP enriched agidi samples may be attributed to the high levels (132-194 $\mu \mathrm{g} / \mathrm{g}$ ) of $\beta$-carotene (a provitamin A) in OFSP (Van Jaarsveld et al., $2005)$. In the body, $\beta$-carotene is converted to the active form of vitamin A in the body. As a standard, $12 \mu \mathrm{g}$ of $\beta$-carotene is equal to $1 \mu \mathrm{g}$ Retinol Activity EquivalentRAE (Tadesse et al., 2015).

Lycopene was found in considerable amounts (0.58$1.65 \mathrm{mg} / 100 \mathrm{~g}$ ) in the agidi samples (Figure 1). The lycopene contents increased with increasing levels of OFSP. There was approximately $184 \%$ increase in the lycopene content of the sample, when $30 \%$ OFSP was included in the formulation. Orange fleshed sweet potati has been shown to be a good source of lycopene which is an important carotenoid associated with several health benefits (Kolawole et al., 2017). Agidi appears white since 


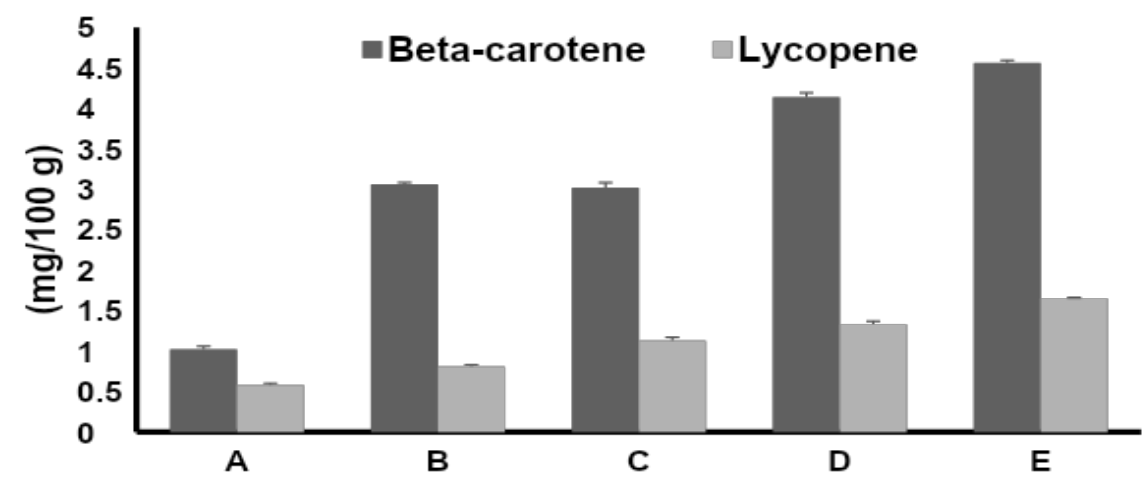

Figure 1: Beta-carotene and lycopene contents of agidi from maize, OFSP and soybean. Error bars indicate standard deviation $(\mathrm{N}=6)$.

Table 5: Colours parameters of agidi from maize, OFSP and soybean.

\begin{tabular}{cccc}
\hline Samples & $\mathrm{L}$ & $\mathrm{a}$ & $\mathrm{b}$ \\
\hline A & $63.92^{\mathrm{a}} \pm 0.46$ & $-1.91^{\mathrm{d}} \pm 0.08$ & $-1.69^{\mathrm{d}} \pm 0.02$ \\
B & $61.30^{\mathrm{b}} \pm 1.15$ & $-1.44^{\mathrm{d}} \pm 0.03$ & $2.90^{\mathrm{c}} \pm 0.17$ \\
C & $60.38^{\mathrm{bc}} \pm 0.40$ & $-0.14^{\mathrm{c}} \pm 0.12$ & $7.75^{\mathrm{b}} \pm 0.47$ \\
D & $57.28^{\mathrm{d}} \pm 0.98$ & $1.32^{\mathrm{b}} \pm 0.45$ & $9.26^{\mathrm{b}} \pm 0.59$ \\
E & $58.38^{\mathrm{cd}} \pm 2.11$ & $2.59^{\mathrm{a}} \pm 1.20$ & $15.99^{\mathrm{a}} \pm 3.17$ \\
\hline
\end{tabular}

Values are means of triplicates (mean \pm standard deviation). Within each column, values with different superscripts differ significantly $(\mathrm{P}<0.05)$. L (lightness) axis -0 is black, 100 is white, a (red-green) axis-positive values are red; negative values are green and 0 is neutral, b (yellow-blue) axis- positive values are yellow; negative values are blue and 0 is neutral.
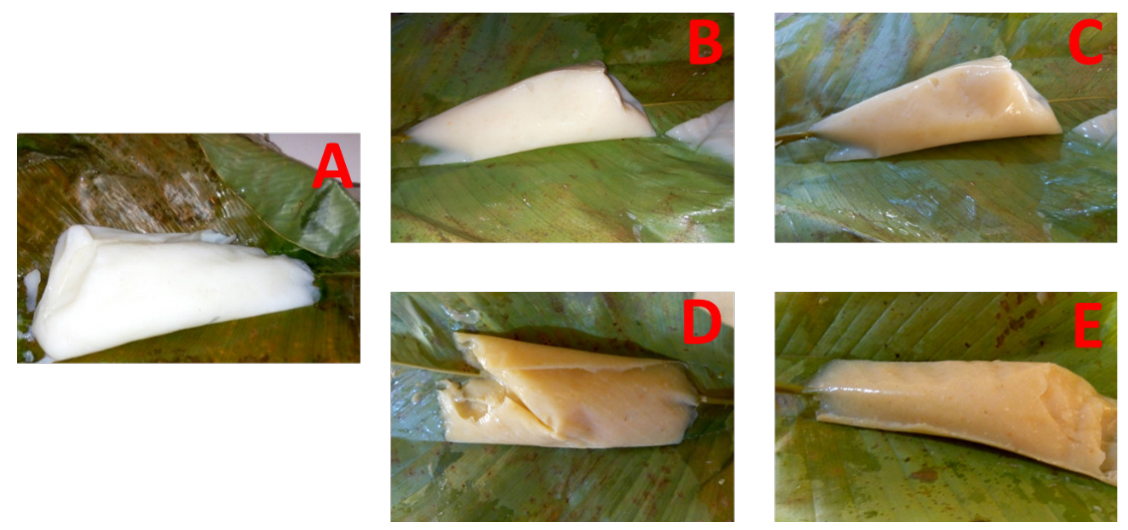

Figure 2: Appearance of agidi from maize, OFSP and soybean.
A: $100 \%$ Maize, $0 \%$ OFSP and $0 \%$ Soybean
D: $70 \%$ Maize, $20 \%$ OFSP and 10\% Soybean
B: $90 \%$ Maize, $10 \%$ OFSP and $0 \%$ Soybean
E: $60 \%$ Maize, $30 \%$ OFSP and $10 \%$ Soybean

C: $80 \%$ Maize, $10 \%$ OFSP and 10\% Soybean

it is usually prepared from white maize, but the colour imparted by the addition of OFSP may further increase the acceptability of the products especially among children.

\section{Colour of agidi samples}

Colour and appearance of food are important quality parameters that determine the acceptability of a food. To assess the impact of OFSP on the agidi samples the objective colour attributes were assessed using a colorimeter. Agidi is known to be white to off-white depending on the grain colour. For example, agidi prepared from yellow maize will have a yellow colour. Color of the samples expressed as Hunter L, ' $a$ ' and ' $b$ ' are presented in Table 5. The lightness (L) value of the samples decreased, while a and b values increased with increasing levels of OFSP. The decrease in $\mathrm{L}$ value suggest a change in colour from the off-white colour, which was accompanied with a corresponding increase in redness and yellowness of the sample. This was confirmed by the appearance of the samples (Figure 2). The samples containing OFSP showed substantial variation in their appearance (Figure 2 B-E) suggesting increase in yellowness as measured by the colorimeter. This colour 
variation may be associated to the presence of colour pigments such as carotenoids in the OFSP sample.

\section{Sensory properties}

The results of the sensory evaluation of the agidi samples are shown in Table 6. There were significant differences $(p<0.05)$ in the sensory attributes measured. The sensory properties were determined using descriptive terms as indicated in Table 2. The control (100\% maize) differed significantly in colour from all the other samples with a highest mean score of 3.25 corresponding to 'plain white colour'. Inclusion of soybean and OFSP resulted in the development of a cream to dull orange colour which gradually increased in intensity in samples containing 10 , 20 and 30\% OFSP. OFSP is rich in beta carotene, which has been reported for its characteristic orange colour (Van Jaarsveld et al., 2005). Values in the range of $1.75-2.15$ were recorded for the various agidi samples in sour taste. The control (100\% maize) had the highest mean score for 'sour taste' which corresponds to the taste of a fermented food while the agidi sample containing 30\% OFSP was described with a sweet potato taste. The sour taste of the control however decreased in intensity with the inclusion of 10\% soybean in 80:10:10 maize-OFSP-soybean sample. A sweet taste corresponding to the taste of sweet potato was reported in the agidi samples with OFSP inclusion. OFSP is known to be characteristically sweet in taste. The sweet taste of OFSP has been reported to be due to its high content of sucrose (Fetuga et al., 2014). There was a significant difference in texture among the agidi samples. The attribute "smooth" was the most rated for the control, 90:10:0, 80:10:10 and 70:20:10 OFSP-soybean agidi samples with mean scores ranging from 3.05 to 4.20 . The attribute "lumpy" was not detected for any of the samples. Mean scores for the attribute "gritty" was significantly different $(\mathrm{P}<0.05)$ among the samples with values of 1.30 , $1.25,2.20,2.05$, and 3.05 for sample A, B, C, D and E, respectively. The increase in the grittiness could be as a result of the levels of the OFSP in the samples. There was a significant difference in consistency among the agidi samples. The control, 90:10:0, 80:10:10 and 70:20:10 OFSP-soybean samples, all recorded means scores corresponding to a moderately thick consistency (3.10 3.45). The agidi samples containing 30\% OFSP, however had a softer, slightly thick slightly watery consistency (2.85 for thick, 2.00 for watery) which needed no pressure to break. They were described to be moistly by the panelist. This is evident in the significant higher moisture contents recorded for agidi samples with OFSP inclusion.

In terms of overall acceptability, the various agidi samples had mean scores ranging from 3.15 to 4.20 with agidi samples containing 10\% OFSP inclusion recording outstanding overall acceptability except for 60:30:10 agidi sample which had the lowest score of 2.65 . The addition of OFSP from 0 to $10 \%$ produced no significant difference in overall acceptability. This indicates that the panelists had a high preference for OFSP fortified-agidi samples. This could be attributed to the orange colour and sweet taste imparted on the agidi samples with the addition of OFSP

\section{CONCLUSION}

Agidi was enriched with soybean and OFSP. Significant changes were observed in the appearance of the sample, which was confirmed objectively using a colorimeter. This study has shown that it is possible to develop a nutritionally and organoleptically acceptable agidi from maize, enriched with OFSP and soybean. Furthermore, because of increased contents of beta-carotene in the samples, the agidi may have antioxidant potentials. The developed product could serve as a food-based approach or strategy to combating vitamin A deficiency and protein-energy malnutrition in developing countries where the syndrome is endemic. Future studies are needed to determine the bioavailability of the nutrients using in-vitro and in-vivo studies.

\section{DECLARATION OF CONFLICT OF INTEREST}

Authors declare no conflict of interest.

\section{ACKNOWLEDGEMENT}

We wish to appreciate the technical support given by the Technologists in the Department of Home Economics and Food Science, University of Ilorin, Nigeria.

\section{REFERENCES}

Abdulrahaman, A. and Kolawole, O.M. (2006). Traditional preparations and uses of maize in Nigeria. Ethnobotanical Leaflets 10: 219-227. https://opensiuc. lib.siu.edu/ebl/vol2006/iss1/23.

Table 6: Sensory evaluation results of agidi from maize, OFSP and soybean.

\begin{tabular}{cccccccccccccc} 
Samples & \multicolumn{3}{c}{ Colour } & \multicolumn{3}{c}{ Taste } & \multicolumn{3}{c}{ Texture } & \multicolumn{2}{c}{ Consistency } \\
\hline & White & Cream & $\begin{array}{l}\text { Pale } \\
\text { orange }\end{array}$ & Bitter & Sweet & Sour & Gritty & Lumpy & Smooth & Watery & Thick & $\begin{array}{l}\text { Overall } \\
\text { acceptability }\end{array}$ \\
\hline A & $3.25^{\mathrm{a}}$ & $1.00^{\mathrm{b}}$ & $1.00^{\mathrm{c}}$ & $1.05^{\mathrm{a}}$ & $2.20^{\mathrm{a}}$ & $2.15^{\mathrm{a}}$ & $1.30^{\mathrm{c}}$ & $1.25^{\mathrm{b}}$ & $3.85^{\mathrm{ab}}$ & $1.15^{\mathrm{c}}$ & $3.45^{\mathrm{a}}$ & $4.20^{\mathrm{a}}$ \\
B & $2.85^{\mathrm{a}}$ & $2.90^{\mathrm{a}}$ & $1.25^{\mathrm{c}}$ & $1.00^{\mathrm{a}}$ & $2.35^{\mathrm{a}}$ & $2.05^{\mathrm{a}}$ & $1.25^{\mathrm{c}}$ & $1.50^{\mathrm{b}}$ & $4.20^{\mathrm{a}}$ & $1.40^{\mathrm{bc}}$ & $3.20^{\mathrm{ab}}$ & $3.95^{\mathrm{a}}$ \\
C & $2.00^{\mathrm{b}}$ & $3.10^{\mathrm{a}}$ & $2.15^{\mathrm{b}}$ & $1.20^{\mathrm{a}}$ & $2.40^{\mathrm{a}}$ & $1.80^{\mathrm{a}}$ & $2.20^{\mathrm{b}}$ & $1.80^{\mathrm{b}}$ & $3.05^{\mathrm{c}}$ & $1.60^{\mathrm{abc}}$ & $3.10^{\mathrm{ab}}$ & $3.75^{\mathrm{a}}$ \\
D & $1.60^{\mathrm{b}}$ & $2.85^{\mathrm{a}}$ & $2.65^{\mathrm{a}}$ & $1.15^{\mathrm{a}}$ & $2.50^{\mathrm{a}}$ & $1.75^{\mathrm{a}}$ & $2.05^{\mathrm{b}}$ & $1.85^{\mathrm{b}}$ & $3.20^{\mathrm{bc}}$ & $1.85^{\mathrm{ab}}$ & $3.40^{\mathrm{ab}}$ & $3.15^{\mathrm{b}}$ & \\
E & $1.75^{\mathrm{b}}$ & $2.45^{\mathrm{a}}$ & $2.70^{\mathrm{a}}$ & $1.10^{\mathrm{a}}$ & $2.75^{\mathrm{a}}$ & $1.85^{\mathrm{a}}$ & $3.05^{\mathrm{a}}$ & $2.50^{\mathrm{a}}$ & $2.20^{\mathrm{d}}$ & $2.00^{\mathrm{a}}$ & $2.85^{\mathrm{b}}$ & $2.65^{\mathrm{b}}$ \\
\hline
\end{tabular}

Mean within the same column having different superscripts are significantly $(\mathrm{p}<0.05)$ different.

Note: $1=$ not at all; $2=$ slightly; $3=$ moderate; $4=$ strong; $5=$ very strong. 
Adeola, A.A., Bamgbose, O.O. and Ohizua, E.R. (2019). Proximate and functional properties of orange fleshed sweet potato/pigeon pea flour blends and extrudates. Applied Tropical Agriculture, 24: 1-12.

Adesokan, I., Fawole, A., Ekanola, Y., Odejayi, D. and Olanipekun, O. (2011). Nutritional and sensory properties of soybean fortified composite ogi A Nigerian fermented cereal gruel. African Journal of Microbiology Research, 5: 3144-3149. https:/doi. org/10.5897/AJMR10.907.

Akobundu, E. and Hoskins, F. (1982). Protein losses in traditional agidi paste production. Journal of Food Science, 47: 1728-1729. https://doi. org/10.1111/j.1365-2621.1982.tb05021.x .

AOAC. (2000). Offcial methods of analysis. 17th edition. In: Asscoaition of official Analytical Chemists, Rockville.

Balogun, M., Kolawole, F., Karim, O. and Fasakin, T. (2016). Proximate Composition, Microbial Quality and Consumer Acceptability of Gruel from Fermented Maize and Soybean. Applied Tropical Agriculture 21: 53-57.

Campagnoli, T.R. and Smiddy, W.E. (2016). Vitamin A Deficiency. In Manual of Retinal Diseases (pp. 611614): Springer.

Fetuga, G., Tomlins, K., Henshaw, F. and Idowu, M. (2014). Effect of variety and processing method on functional properties of traditional sweet potato flour ("elubo") and sensory acceptability of cooked paste ("amala"). Food Science and Nutrition, 2, 682-691. https://doi. org $/ 10.1002 /$ fsn 3.161

Ikya, J., Gernah, D. and Sengev, I. (2013). Proximate composition, nutritive and sensory properties of fermented maize, and full fat soy flour blends for "agidi" production. African Journal of Food Science, 7: 446-450.

Kolawole, F.L., Balogun, M.A. and Sanni-Olayiwola, H. O. (2017). Physical and chemical characteristics of moringa-fortified orange sweet potato flour for complementary food. Croatian Journal of Food Technology, Biotechnology and Nutrition, 12: 37-43. https://hrcak.srce.hr/189311.

Kolawole, F.L., Balogun, M.A., Oyeyinka, S.A., Adejumo, R.O. and Sanni-Olayiwola, H. O. (2020). Effect of processing methods on the chemical composition and bio-accessibility of beta-carotene in orangefleshed sweet potato. Journal of Food Processing and Preservation, 44: e14538. https://doi.org/10.1111/ jfpp. 14538.

Kumari, D., Reddy, M.S. and Upadhyay, R.C. (2011). Antioxidant activity of three species of wild mushroom genus Cantharellus collected from North-Western Himalaya, India. International Journal of Agriculture and Biology, 13: 415-418. http://www.fspublishers.org/ ijab/past-issues/IJABVOL_13_NO_3/20.pdf .

Nafiu, M.O., Akanji, M.A. and Yakubu, M.T. (2011). Phytochemical and mineral constituents of Cochlospermum planchonii. Hook. Ef. $x$ Planch) Root. Bioresearch Bulletin, 5: 342-347.

Nuss, E.T. and Tanumihardjo, S.A. (2010). Maize: a paramount staple crop in the context of global nutrition.
Comprehensive Reviews in Food Science and Food Safety, 9: 417-436. https://doi.org/10.1111/j.15414337.2010.00117.x .

Ogiehor, I., Ekundayo, A. and Okwu, G. (2005). Shelf stability of agidi produced from maize (Zea mays) and the effects of sodium benzoate treatment in combination with low temperature storage. African Journal of Biotechnology, 4: 738-743. https://doi.org/10.5897/ AJB2005.000-3134.

Oguche, G.H.E., Okudu, H.O. and Ikani, I.T. (2017). Energy, proximate and sensory attributes of soyfortified "agidi. Direct Research Journal of Agriculture and Food Science, 5: 161-164.

Osungbaro, T. (1990a). Effect of period on Amylose Content and Textural Characteristic of ogi (A fermented maize starch porridge) and agidi (fermented maize starch gel). Journal of Tropical Research, 14: 102-109.

Osungbaro, T.O. (1990b). Effect of fermentation period on amylose content and textural characteristics of "Ogi"(a fermented maize porridge). Journal of Fermentation and Bioengineering, 70: 22-25. https:// doi.org/10.1016/0922-338X(90)90024-Q.

Otunola, E., Ogunsola, O. and Abioye, V. (2006). Effect of tempeh on some properties of 'agidi', a West African fermented maize gel. International Journal of Food and Agriculture and Research, 3: 119-128.

Oyeyinka, S.A., Adeleke, O.F., Dauda, A.O., Abiodun, O. A., Kayode, R.M. and Adejuyitan, J.A. (2018a). Flour composition and physicochemical properties of white and yellow bitter yam (Dioscorea dumetorum) starches. Industrial Crops and Products, 120: 135-139. https:// doi.org/10.1016/j.indcrop.2018.04.061.

Oyeyinka, S.A., Tijani, T.S., Oyeyinka, A.T., Arise, A. K., Balogun, M.A., Kolawole, F.L., Obalowu, M.A. and Joseph, J.K. (2018b). Value added snacks produced from Bambara groundnut (Vigna subterranea) paste or flour. LWT-Food Science and Technology, 88: 126-131. https://doi.org/10.1016/j.lwt.2017.10.011.

Ranhotra, G., Gelroth, J., Leinen, S., Vinas, M. and Lorenz, K. (1998). Nutritional profile of some edible plants from Mexico. Journal of Food Composition and Analysis, 11: 298-304. https://doi.org/10.1006/jfca. 1998.0590

Tadesse, T.F., Nigusse, G. and Kurabachew, H. (2015). Nutritional, Microbial and Sensory Properties of Flatbread (kitta) Prepared from Blends of Maize (Zea mays L.) and Orange-fleshed Sweet Potato (Ipomoea batatas L.) Flours. International Journal of Food Science and Nutrition Engineering, 5: 33-39.

van Jaarsveld, P.J., Faber, M., Tanumihardjo, S.A., Nestel, P., Lombard, C.J. and Benadé, A.J.S. (2005). $\beta$-Carotene-rich orange-fleshed sweet potato improves the vitamin A status of primary school children assessed with the modified-relative-dose-response test. The American Journal of Clinical Nutrition, 81: 1080-1087. https://doi.org/10.1093/ajcn/81.5.1080.

Zakari, U., Hassan, A. and Abbo, E. (2010). Physicochemical and sensory properties of "agidi" from pearlmillet (Pennisetum glaucum) and Bambara groundnut (Vigna subterranea) flour blends. African Journal of Food Science 4: 662-667. https://doi.org/10.5897/ AJFS.9000224. 